seven years of age, who, it was easy to see, had been run over in one of the busy thoroughfares outside, and had got his leg broken. His father and mother had come to see him. Absurdly young they both looked, to be the parents of a seven years old boy, and I watched them as they sat, one on either side of the bed, without speaking either to each other or to the patient, for quite four or five minutes. The lad himself, if the truth must be told, looked by far the least miserable of the three; and this peculiarity has often struck me before in my peregrinations through one hospital and another. The infantile and youthful in-patients, as soon as they get the least bit convalescent, are undoubtedly, in ninety-nine cases out of a hundred, better off there than at home. A sick child, even though it be uglythat is, if an ugly child be possible : a point I have often heard kind-hearted matrons hotly dispute-is always interesting, and very often most lovable. Aceordingly, all the good things of the hospital life fall abundantly to his or her share, and the happiness depicted on the faces of the child-inmates is not at all to be wondered at. But this is a digression. In the very next room I came across one who had pretty nearly reached the end of the seventh act in life's drama-an old woman visited by her daughter, who, as she talked to the patient, held her baby to her breast. I should have liked to inquire into their history had I dared. The old woman looked as if life for her had been one long battle; nor had the combat been gentle, apparently, with the younger one, whilst the baby was but meanly clad. Yet care was apparently forgotten just then, and the two women conversed in a low, eager tone, which proclaimed to all and sundry that they were determined to make the most of the short visiting hour.

If, however, visiting day is a pleasure to those patients who have visitors, it does not appear to bring much joy to the friendless ones, some of whom wore on their faces an expression very like envy towards their more fortunate fellows. Human nature is the same inside as outside the walls of a hospital, and the visitorless patient, especially if she be a woman, no doubt feels the loneliness more when friends are seated near all the neighbouring beds, whilst her own bedside is empty.

One more incident, and I have done. Having occasion to call at the secretary's offices, it happened that I entered the door at the same time as a patient who was just about to be discharged. He was of the workingclass-so much was evident from his manner and speech -but his period of confinement had been long, and all the horny-handedness had disappeared, his palm and fingers being as plump and soft as a lady's. He had come to get an order for some appliance of mechanical surgery, and between him and the clerical official, who was seated at a desk, the following conversation took place :

"So you're going out. Have you been comfortable since you've been here?" "Yes" (this with very great emphasis). "Are you better?" "Oh, yes! I shall soon be as strong as ever I was." "And you've no complaint to make of anything or anybody?" The man looked for a moment as if he thought his interrogator was poking fun at him; but observing that the gravity of the gentleman's face remained unshaken, he replied, "Complaint, sir! Nothing whatever." Then he took his ticket and went out.

When I passed into the street the rain had ceased and the sun was shining brightly. The devotees of $l a$ haute politique were hurrying down to the House, and the Row was beginning to show signs of animation.

\title{
LUNATIC LITERATURE.
}

\section{By a Voluntary Commissioner.}

LIFE in a lunatic asylum must always be more or less of a nursery existence. The chief effort of those in authority must be to keep their grown-up children "good" by every device that can be invented for their amusement; but it does not follow that the games the patients play at are wholly trivial or silly. Many forms of mania, which unfit a man for taking an active part in life, leave his general intellectual and social qualities almost unimpaired, and the exercise of these faculties, besides keeping the patient from becoming morbid, gives to the little world of the asylum its microcosmic labours and ambitions, amusements and castes.

Some of the larger asylums publish a magazine, the contributors to which are patients, and the poems and articles in these journals are by no means so insane as the outside world might expect. Many of the papers deal with the great excitements of the asylum. Lectures, concerts, and balls are reported with a fulness of detail that show how much the writers enjoyed their occurrence. In the description of a dramatic recital, which we take from the pages of The Morningside Mirror, the journal of the Edinburgh asylum, even the dresses of the lady performers are de- scribed with artistic fervour:- "The three Graces were all dressed alike, in pretty and quaint costumes of green plush or velveteen, the play of light from bright to dark green giving all the appearance of a rich shot-silk velvet (if such there be)."

Less æsthetic sentiments fill the mind of the writer who describes the Christmas, Hallowe'en, and other balls; for besides speaking in favourable terms of the music and the floor, and the vigour with which dancing was kept up, he invariably details what manner of good things were provided for supper. Other paragraphs contain reports of chess contests and cricket matches, with elaborate criticism of moves and runs. In one number is given a metrical description of a game at chess, some of the stanzas of which take a satiric turn :-

$$
\begin{aligned}
& \text { "Set all the foot-soldiers } \\
& \text { In front of the play, } \\
& \text { They've pawned their small bodies } \\
& \text { For rations and pay ; } \\
& \text { They're sure to be killed } \\
& \text { Ere the nobles appear, } \\
& \text { For the latter are prudent } \\
& \text { And keep in the rear." }
\end{aligned}
$$

Some of the prose articles, however, are more serious 
in import than this reporting work. One writer discourses with varied, if not profound, learning on the Odes of Anacreon. That these notes on the Greek poet, in which the author assumes that his readers are familiar with the original Greek, though he occasionally is generous enough to quote from Moore's translation, would meet with popular favour is somewhat doubtful. Probably no one else profited so much by the writing of them as the author himself. More likely to interest the average mind are the reminiscences of "College Life Forty Years Ago,"- though to an outsider there is something pathetic in the inmate of an asylum sitting down to record the habits of days when the life, now so sadly clouded, was illuminated with the hope and energy of youth.

But it is when the patients quit the dull level of prose and, like Mr. Silas Wegg, "drop into verse," that their work shows most originality and freedom. The Morningside Mirror, like more famous journals, has its Jubilee Ode, as loyal as need be, though dwelling more on national gains and glories than the effusions of Lords Tennyson and Rosslyn. After describing, with perhaps too much detail, the wondrous works of steam and electricity, and the results of war and colonisation, the poet bursts out in a strain of true John Bull exultation :-

$$
\begin{aligned}
& \text { "Who are first in thought and action, } \\
& \text { Who are foremost in the strife? } \\
& \text { We. the children of Victoria, } \\
& \text { Mother of the nation's life." }
\end{aligned}
$$

Immediately after he falls into a sadder and more practical strain. He anathematises over-education, and gives the advice :-

$$
\begin{aligned}
& \text { "Let us not have too much schooling, } \\
& \text { Making boys grew nervous, vain; } \\
& \text { Too much brain is worst of fooling, } \\
& \text { Let us use our hands again." }
\end{aligned}
$$

Returning at the end of his poem to the ostensible subject of it, he addresses to the Queen at least one not unworthy stanza :-

\section{"Sorrow's shafts have often struck thee- All who live feel grief and wrong- But the soul is cleared by sorrow, And the struggle maketh strong."}

It is, however, in verse of less serious import that the poet-patients show to most advantage. Though we on the outside of the asylum walls are apt to think that humour is in a very special way a characteristic of sanity, we are forced to admit that a pretty keen sense of the comic possibilities of life and literature is displayed within them. There is a pretty fair mock Spenserian, or at least Shenstonian flavour in the "Elegy on the Lamented Decease of Canis Tauserius," as one stanza may show :-

"At a cat near top of tree high-perched, sublime, He wouid loudly bark with glee most strenuously, And at the foot would wait great length of time, Barking for hours in wonder's ecstasy :

And shaking tail, sit'neath the o'erbranching bower, To make the woods with doggish tones resound,-Ceaseless denouncing cats with all his power, To wake the echoes in the glooms profound! His fearful barks the neighbours would alarm, As if a foreign foe had seized the land,

nd there were cause to dread some deadly harm

And he were ambitious of a war-command !"

In the satiric, lightly reflective strain of the vers de societ is the song, somewhat over-burdened with technical phrases, entitled "The Bard in the Billiard Room"-

$$
\begin{aligned}
& \text { "Chalk the cue and pot the red- } \\
& \text { You must take it from the D-- } \\
& \text { Cunning hand and canny head, } \\
& \text { What are all your skill to me? } \\
& \text { I have marked your breaks and misses, } \\
& \text { Perched aloft above the fray,- } \\
& \text { Pockets, cannons, flukes, and kisses ; } \\
& \text { Best of all is one away. } \\
& \text { "Time and change, and wear and tear, } \\
& \text { Try all things beneath the blue, } \\
& \text { Tunnel through the chalk four-squa e, } \\
& \text { Loose the leather from the cue. } \\
& \text { Longest breaks at last are ended; } \\
& \text { Every dog must have its day: } \\
& \text { Clouds shall pass, and cues be mended, } \\
& \text { And the Bard be one away." }
\end{aligned}
$$

Perhaps one of the cleverest things that asylum literature has produced is an ode addressed to the Cheshire cat, a mystic animal known to the readers of Alice in Wonderland, which parodies the somewhat verbose measures of Mr. Swinburne's verse :-

$$
\begin{aligned}
& \text { " Green eye-balls, that gleam like a station, } \\
& \text { When the signals are lit for the night; } \\
& \text { Fierce whiskers and wild exultation } \\
& \text { Of a grin full of feline delight: } \\
& \text { Of a grin full of feline delight: } \\
& \text { Dark answers that never make plain, } \\
& \text { And a form that fades wholly, and rallies } \\
& \text { To vanish again. }
\end{aligned}
$$

Such examples as these of lunatic literature show the bright side of asylum life, and prove that energy and happiness are not wholly lost by those unfortunates to whom we so often give a half-contemptuous pity. But at best it can be only the silver lining to a most gloomy cloud, "bright by excess of dark." We have spoken of it as a nursery existence. Recalling how many hopes are blighted, ambitions quenched, and hearts wounded by the shadow on the minds of those whose best lifework consists of such trifles as we have quoted, we are tempted to murmur sadly the words of Wendell Holmes :-

"Our nursery joys We know must have an end But love and friendship's broken toys May God's good angels mend !", 